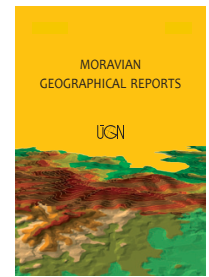

MORAVIAN GEOGRAPHICAL REPORTS

\title{
Channel migration inferred from aerial photographs, its timing and environmental consequences as responses to floods: A case study of the meandering Topla River, Slovak Carpathians
}

\author{
Miloš RUSNÁK a *, Milan LEHOTSKÝ a, Anna KIDOVÁ a
}

\begin{abstract}
The bank erosion area, rate of bank retreat and overall geomorphological and financial effects of channel migration due to recent flood events (over the time span 1987-2009) are identified using remotely sensed data and GIS. A 39 km-long reach of the meandering, gravel bed Topl'a River (Flysch Slovak Carpathians) was selected as the study area. Based on the analysis of culmination discharges, two different flood periods are identified. The first one (1987-2002) is characterised by the dominance of low magnitude flood events, compared to the second one (2002-2009) with higher magnitude floods. Aerial photographs from 2002 and 2009 were chosen as a way to capture the morphological changes that occurred after the flood periods, while those from 1987 served as the reference point. In total, an area of $85.2 \mathrm{ha}$ was eroded and 60.1 ha were deposited. The average channel shift per year doubled from $0.8 \mathrm{~m} /$ year (1987-2002) to $1.6 \mathrm{~m} /$ year (2002-2009). The most eroded land cover category in the riparian zone is floodplain forest, followed by arable land, grasslands and pastures and shrubs. From an economic point of view, the eroded floodplain with arable land and grassland (€ 29,924.02 in total) is a negative consequence of channel migration.
\end{abstract}

Key words: river channel migration, flood, bank erosion, land cover, erosion risk, Slovakia

Article history: Received 20 October 2015; Accepted 15 February 2016; Published 30 September 2016

\section{Introduction}

Most river channels develop bends in reaches with erodible materials and low gradient. Flow energy in such sinuous channels is concentrated along the concave bank in bends, while deposition occurs at the convex one. Fastmoving water on the outside bend erodes the bank, picks up the sediment and drops it when the water slows at the inside of the next downstream bend. This increases the length of the channel, which helps dissipate the energy of the flowing water over a longer distance. Streambank retreat, frequently called streambank erosion, occurs by a combination of three processes: subaerial processes, fluvial entrainment and mass wasting. To provide clarity for the remainder of the article, the authors have adopted the terminology proposed by Lawler et al. (1997). Specifically, the terms "fluvial erosion" and "fluvial entrainment" are used to describe the detachment, entrainment and removal of individual soil particles or aggregates from the streambank face by the hydraulic forces occurring during flood events. The terms "bank failure" or "mass wasting" denote the physical collapse of all or part of the stream banks as a result of geotechnical instabilities. Bank erosion and bank failure commonly work in concert to produce bank retreat.

Thus, bank erosion on one hand and deposition/ reworking of bank-attached geomorphic units along the convex bank on the other hand, promote lateral migration of the channel. Studies have shown that the sediment from stream banks counts for as much as $85 \%$ of watershed sediment yields and bank retreat rates as high as $1.5 \mathrm{~m}^{-1}, 100 \mathrm{~m} /$ year (Simon et al., 2000). In addition to water quality impairment, stream bank retreat impacts floodplain residents, riparian ecosystems, bridges and other stream-side structures. River bank erosion is seen as a part of long-term channel change, meander migration and floodplain development and destruction.

\footnotetext{
a Institute of Geography, Slovak Academy of Sciences, Bratislava, Slovakia (*corresponding author: M. Rusnák, e-mail: geogmilo@savba.sk)
} 
In recent years, floods following heavy precipitation have occurred with increasing but unpredictable frequency in many European countries. Many authors (e.g. Bronstert, 2003; Brázdil et al., 2006; Langhammer, 2010; Pekárová et al., 2003, 2010) point out the cyclical character of flood events and have identified several dry and wet periods during the last century in many world and Slovak rivers. Dry and wet periods are likely to be conditioned by the North Atlantic Oscillation (NAO) phenomenon (Pekárová, et al., 2010).

Hence, understanding streambank erosion hazards in response to recent floods calls for analyses of the links between floods and river behaviours at the regional to local scale (Langhammer and Vilímek, 2008; Brázdil et al., 2011) The long-term response to a series of flood events manifests itself first in the inner-channel organisation of landforms. The temporal distribution of flood events reflects the overall climatic conditions of the region and responds to the precipitation regime. The impact of floods depends on the morphological state of the channel (sinuosity, pattern, gradient) during high flow events, and the geological and morphological (topographical) conditions of the river catchment (Hooke, 2015). Further variables which affect the response of the channel system to floods, are changes in vegetation cover (succession, seasonality and land use), as they partially influence the sediment supply or flood capacity of the channel. Similar floods in terms of magnitude and frequency, however, can produce dissimilar morphological responses (Fuller, 2008). Michalková et al. (2011) point out the significant geomorphological effect of a critical shear stress, which is recorded under the influence of more frequent and prolonged floods. Hickin and Sichingabula (1988) highlight the importance of the flood duration. In general, they consider that smaller but longer duration floods are more constructive, while high magnitude floods are destructive. The effects of small magnitude and frequent floods are constructive and contribute to accretion of sediments and stabilisation of the channel (Corenblit et al., 2007).

Bank erosion is closely connected with flood events characterised by the increase of stream power. It leads to an increased rate of erosion/deposition processes in the channel (Hooke, 1979; Miller, 1990; Hrádek, 2000; Richard et al., 2005; Larsen et al., 2006; Kiss et al., 2008; Pišút, 2008). Bank erosion processes depend on the size of the discharge and the interactions between the ever-changing hydrological conditions (the flow velocity, local hydraulics, floods and their magnitude, frequency, duration and timing) and other factors contributing to bank erodibility (initial bank geometry, planform geometry, height and density of vegetation, volume of accessible sediments, sediment grain size) (Knighton, 1998; Russell et al., 2004; Luppi et al., 2009), as well as floodplain land cover and overall riverine landscape management.

The successful and sustainable management of rivers requires awareness of which river reaches are prone to bank destruction and any subsequent lateral shifts (Brierley and Fryirs, 2005; Richard et al., 2005; Fryirs and Brierley, 2013). Piégay et al. (2005) report several ways of delimiting the erodible corridor. Historical analysis based on data obtained by remote sensing and historical maps, offers an ideal source for the definition of river channel mobility and the identification of both stable and unstable reaches. It is less applicable, however, for the prediction of future instability and lateral shift.
Aerial photos capture high-resolution details of the changing fluvial landscape (Bryant and Gilvear, 1999). The greatest advantage though, is their temporal and spatial flexibility in the mapping of changes. Their benefit lies in the accessibility of dense and highly accurate information (dependent on resolution), which allows relatively precise quantification of morphological processes (bank erosion, planform changes, bar accumulation, etc.). The accuracy and precision of spatial data, methods for calculating lateral movement of the channel and the selection of consistent rules for identifying landform dynamics and delimiting the features of interest, significantly affect geomorphological interpretations (Zanoni et al., 2008). Not only do historical data serve to identify lateral migration (Hooke, 1979; Pišút, 2002; Gilvear and Bryant, 2003; Michalková et al., 2011), but they also contribute to the study of changes of channel and riparian zone patterns (Bryant and Gilvear, 1999; Gilvear and Willby, 2006). Floods and their erosional power affect the overall ecological diversity in the riparian landscape by eroding channel landforms or vegetation in the riparian zone, by depositing sediments and seed dissemination (Ward et al., 2002; Gurnell and Petts, 2002, 2006; Corenblit et al., 2007; Opperman et al., 2010; Corenblit et al., 2010; Erskine et al., 2012).

The aim of this paper is to identify bank erosion areas, the rate of bank retreat and its financial consequences. The paper also investigates the links between bank erosion and land cover categories in the riparian zone, and the overall geomorphological effects of channel migration and its timing, due to recent flood events between 1987 and 2009 in a gravel bed, minimally regulated and laterally partlyconfined meandering watercourse.

\section{Study area}

The research has been carried out over a $39 \mathrm{~km}$ central reach of the Topla River, a gravel-bedded, non-regulated channel (Fig. 1) in the outer Carpathians flysch setting in Eastern Slovakia (Central Europe). The river springs at an altitude of 1,015 $\mathrm{m}$ a.s.l. in the mountain range of Čergov. It is $115 \mathrm{~km}$ long before it reaches the point of confluence with the River Ondava. The area of its basin is 1,506.4 $\mathrm{km}^{2}$; the long-term daily average discharge at the Bardejov gauging point oscillates at a level of $\mathrm{Q}=3.018 \mathrm{~m}^{3} \cdot \mathrm{s}^{-1}$ $\left(\mathrm{Qmax}=350 \mathrm{~m}^{3} \cdot \mathrm{s}^{-1}\right.$ (17. 05. 2010)). The Topla River in the study reach is a $6^{\text {th }}$ order stream (Strahler order). The catchment is built by Eocene claystones, sandstones and conglomerates. The floodplain of the Topla River is filled with Holocene gravels and sandy gravels and the valley slopes are affected by landslides. The thickness of the layers varies between 2-8 m (Kováčik et al., 2011).

The river basin is considerably forested with a total cover of 52\% (CORINE land cover 2006). Agricultural landscape is represented by the category of arable land, concentrated along the valley bottoms, and covers $24.4 \%$ of the catchment. Dikes are built on the left bank near the town of Giraltovce (length $670 \mathrm{~m}$ ) and in the town of Bardejov (length $150 \mathrm{~m}$ ). A small hydropower plant was constructed between 1987 and 2002 in a meandering reach of the river south of Bardejov. Stony bank revetments were built in several places (to a total length of $1,990 \mathrm{~m}$ ) where the river threatened roads, bridges or arable land. These bank protection practices were mapped: the longest bank revetment is $300 \mathrm{~m}$ long. These works only have a very local effect, however, and the Topl'a preserves its natural state. 


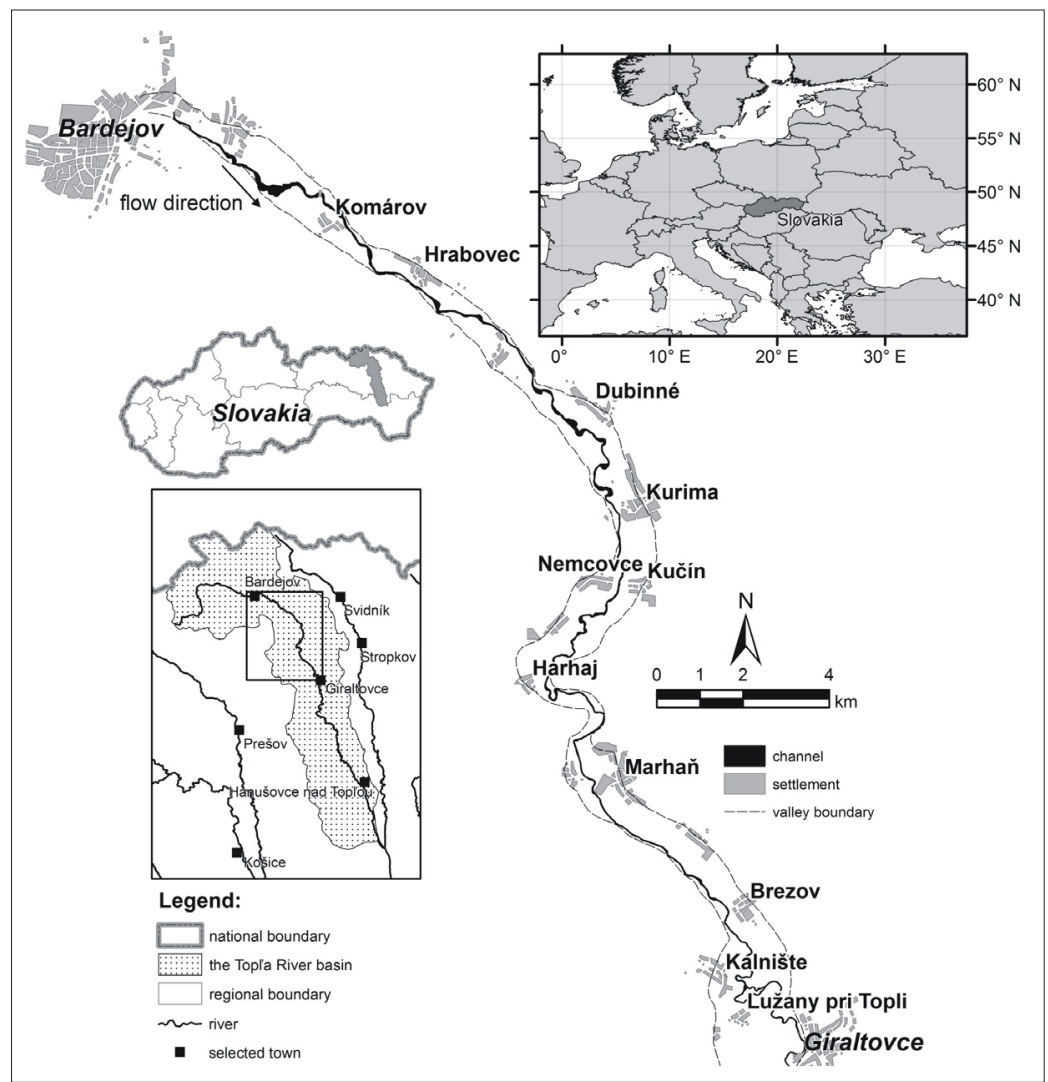

Fig. 1: Location of the Topl'a River catchment and the study reach. Source: GIS data: Geodesy, Cartography and Cadastre Authority of Slovak Republic (122-24-99-2012); authors' elaboration

\section{Methods}

The post-flood period serial geomorphic analysis (POPSEGA, Kidová et al., 2016) approach has been used as the methodological template. The analysis of daily average discharges (data provided by the Slovak Hydrometeorological Institute (SHMÚ) from the Bardejov gauging station located immediately upstream from the study reach) and the analysis of culmination discharges (which were defined as the $3^{\text {rd }}$ level of flood alert declared by the SHMÚ), allowed us to identify two different flood periods. The first one (1987-2002) is characterised by the dominance of low magnitude events, whilst during the second one (2002-2009) higher magnitude floods are typical.

Spatial data about the channel, the in-channel landforms and the riparian zone land cover were generated from remote sensing images (aerial photographs and orthophotographs). The photographs were chosen in such a way that the morphological changes that occurred after flood periods were captured. They were analysed in three time horizons (1987 as reference,and 2002 and 2009 as the post-extreme flood events) applying ArcGIS in the S-JTSK (Krovak East North) coordinate system. Black-and-white aerial photographs (taken on July 7, 1987 and August 23, 1987, pixel resolution $0.5 \mathrm{~m}$ ) and colour orthophotos (second half of June 2002 with pixel resolution $1 \mathrm{~m}$, and from April 15, 2009, pixel resolution of $0.89 \mathrm{~m}$ ), were the sources of spatial data. Aerial photographs were taken at similar low flow conditions, which is important to minimize differences caused by varying water levels during vectorisation of channel landforms (mainly gravel bars, Tab. 1). Discharges at the time of imagery were similar to the average daily discharges. A limitation of the method is that the images capture the state of the channel at the moment of imaging and do not record the process of changes that take place between individual events; this leads to a problem with the assessment and definition of changes and the identification of the contribution of individual change attractors (Hooke and Redmond, 1989; Draut et al., 2011).

The raster sources obtained were used to identify the bank edge (channel); the in-channel forms (bars) and the land cover structures of the riparian zone. The bank edge was traced either along the visible bank line or, in the case of the canopy cover impeding its distinct position, it

\begin{tabular}{lccccccc}
\hline & Daily average & \multicolumn{5}{c}{ Date of aerial photograph } \\
\cline { 3 - 9 } & Qa (1967-2009) & \multicolumn{2}{c}{1987} & \multicolumn{2}{c}{$2002(15 .-30.6)}$. & \multicolumn{2}{c}{2009} \\
& Hd (1987-2009) & $7 / 7 / 1987$ & $23 / 8 / 1987$ & max. & average & $15 / 4 / 2009$ & $26 / 8 / 2009$ \\
\hline discharge Qa $\left[\mathrm{m}^{3} \cdot \mathrm{s}^{-1}\right]$ & 3.017 & 1.975 & 1.439 & 2.259 & 1.465 & 4.078 & 1.485 \\
water level $\mathrm{Hd}[\mathrm{cm}]$ & 155.1 & 155.3 & 151.54 & 156 & 150.76 & 159 & 149 \\
\hline
\end{tabular}

Tab. 1: Hydrological characteristics of the River Topl'a at the Bardejov gauge station (daily average discharge (Qa) and daily average water level $(\mathrm{Hd})$ on the date of aerial photographs. Spatial data were recorded during similar flow conditions. Source: Data (Slovak Hydrometeorological Institute) 
was drawn in an approximate position based on the field survey of the treetop size. Bank erosion was assessed by overlapping bank positions in three time horizons according to the methodology of Lehotský et al. (2013) and Rusnák and Lehotský (2014). The spatial aspect of the individual parameters of the lateral shift, gravel bars and bank erosion was expressed for $250 \mathrm{~m}$ segments (154 up-stream numbered segments in total). During the field research trips (20112014), individual morphological forms and processes were identified. Thus, data were gained about the erosion and the deposition area, as well as the direction and the size of the individual bank shifts. As for in-channel landforms, four types of channel landforms were identified: a) lateral bars, b) point bars, c) central bars, and d) islands. The main criterion for distinguishing between bars and islands was vegetation cover. Bars were identified as landforms without vegetation or low vegetation cover of less than $25 \%$, and islands with a tree vegetation cover of more than $70 \%$. The resolution of raster data influenced the amount of detail and the size of interpretation objects. The limit for identification of lateral shift was $1 \mathrm{~m}$ (1 pixel) and the landforms were digitised if one dimension exceeded $3 \mathrm{~m}$ (3 pixels).

The land cover of the riparian zone was investigated in the buffer zone of $20 \mathrm{~m}$ away from the bank lines obtained for 1987, 2002 and 2009. Its width, $20 \mathrm{~m}$, is considered the floodplain space sufficient to capture bank line shift during the study time span. In total, five land cover categories were defined:

1. riparian forest (tree cover more than $70 \%$ ) as a mature stage of the development in the riparian vegetation;

2. shrubs;

3. grassland and pastures;

4. arable land; and

5. urbanised areas (built-up surfaces, among which gardens, urban greenery or other man-made technical structures can be found).

The social aspect of bank erosion was assessed according to the monetary value of destroyed plots, which is defined by the Decree of the Ministry of Agriculture and Rural Development of the Slovak Republic about prices of plots and growths on such plots for the purpose of land consolidation (Decree No. 38/2005). This Decree contains prices set by the
Government. The prices are based on the soil quality of plots classified by the so-called bonity soil-ecological units. The values of plots were established only for categories 3 and 4 (grassland and arable land). Forests in the buffer zone (categories 1 and 2) were excluded because they are not economically exploited. The economic value established by this method reflects the prices set by the Government, which differ from market prices.

\section{Results}

\subsection{Analysis of flood events}

Mean daily discharges oscillate around $3.018 \mathrm{~m}^{3} \cdot \mathrm{s}^{-1}$, but the maximum discharge in the relevant period of 1987-2009 was $235 \mathrm{~m}^{3} \cdot \mathrm{s}^{-1}$ in May 1987 (20-year recurrence interval, RI20). After the distinct flood event of 1987 and the flooding in 1989 (with a 5-year recurrence interval, RI5), there was a period of reduced flood activity with the maximum discharge corresponding to a 1 or 2 -year recurrence interval (Fig. 2). Flood events of greater importance appeared after the year 2000 and particularly in $2004\left(\mathrm{Q}_{\mathrm{dmax}}=207 \mathrm{~m}^{3} \cdot \mathrm{s}^{-1}\right.$ [20-year recurrence interval] $), 2006\left(\mathrm{Q}_{\mathrm{dmax}}=160 \mathrm{~m}^{3} \cdot \mathrm{s}^{-1}\right.$ [10-year recurrence interval]) and $2008\left(\mathrm{Q}_{\mathrm{dmax}}=218 \mathrm{~m}^{3} \cdot \mathrm{s}^{-1}\right.$ [20-year recurrence interval]). Larger floods also appeared in $2000\left(\mathrm{Q}_{\mathrm{dmax}}=92 \mathrm{~m}^{3} \cdot \mathrm{s}^{-1}\right.$ [from 2 to 5 -year recurrence interval]), $2001 \quad\left(\mathrm{Q}_{\mathrm{dmax}}=76 \mathrm{~m}^{3} \cdot \mathrm{s}^{-1}\right.$ [2-year recurrence interval]), $2002\left(\mathrm{Q}_{\mathrm{dmax}}=82,1 \mathrm{~m}^{3} \cdot \mathrm{s}^{-1}\right.$ [from 2 to 5 -year recurrence interval]) and in $2005\left(\mathrm{Q}_{\mathrm{dmax}}=103 \mathrm{~m}^{3} \cdot \mathrm{s}^{-1}\right.$ [from 2 to 5-year recurrence interval]). Based on the above, two different flood periods, i. e. 1987-2002 and 2002-2009 were identified. The first flood period (1987-2002) is characterised by the occurrence of the floods from a 1 to 2 -year recurrence interval. The second flood period (2002-2009) represents a series of high magnitude and high frequency flood events with a recurrence interval from 5 to 20 years. The periods correspond to wet and dry periods identified by Pekárová et al. (2010).

\subsection{Bank lateral shift and changes in bedforms}

A typical feature of the Topla River channel is its lateral dynamics and distinct bank erosion. In total, an area of 85.2 ha was eroded and 60.1 ha was deposited (the area of the former channel which became a part of the floodplain) in the period 1987-2009 (Tab. 2).

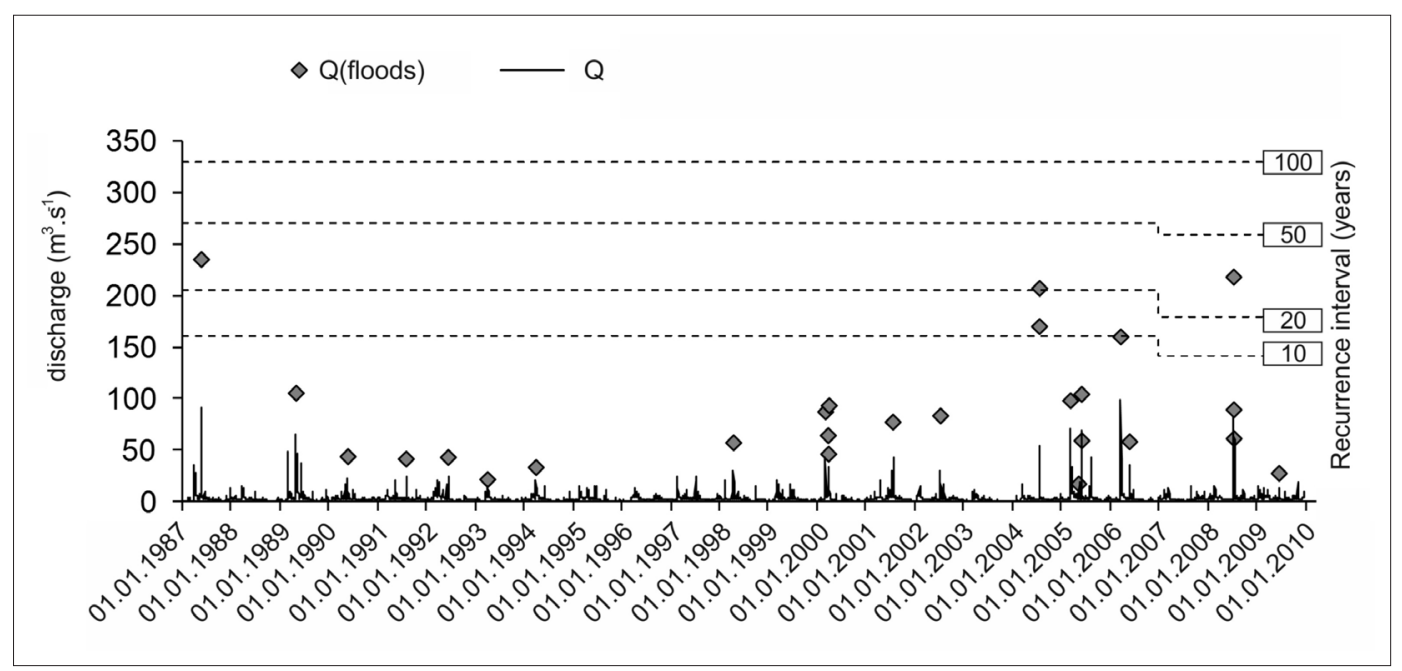

Fig. 2: Variability of daily average discharges (Q) in the period 1987-2009 on the Topl'a River recorded at the Bardejov gauge station, discharge of flood events and recurrence interval over the same period

Source: Data (Slovak Hydrometeorological Institute); authors' elaboration 


\begin{tabular}{lcccc}
\hline \multirow{2}{*}{ Flood period } & \multirow{2}{*}{$\begin{array}{c}\text { Area of erosion } \\
\text { total }\left[\mathbf{m}^{\mathbf{2}}\right]\end{array}$} & $\begin{array}{c}\text { Area of deposition } \\
\text { total }\left[\mathbf{m}^{\mathbf{2}}\right]\end{array}$ & \multicolumn{2}{c}{$\mathbf{m}^{\mathbf{2}} /$ year } \\
\cline { 4 - 5 } & 318,047 & 424,204 & erosion/year & deposition/year \\
\hline 1987-2002 & 534,063 & 176,951 & 21,203 & 28,280 \\
$2002-2009$ & & 76,295 & 25,279 \\
\hline
\end{tabular}

Tab. 2: The area of erosion and deposition and the rate of erosion/deposition per year in the periods 1987-2002 and 2002-2009. Source: authors' calculations

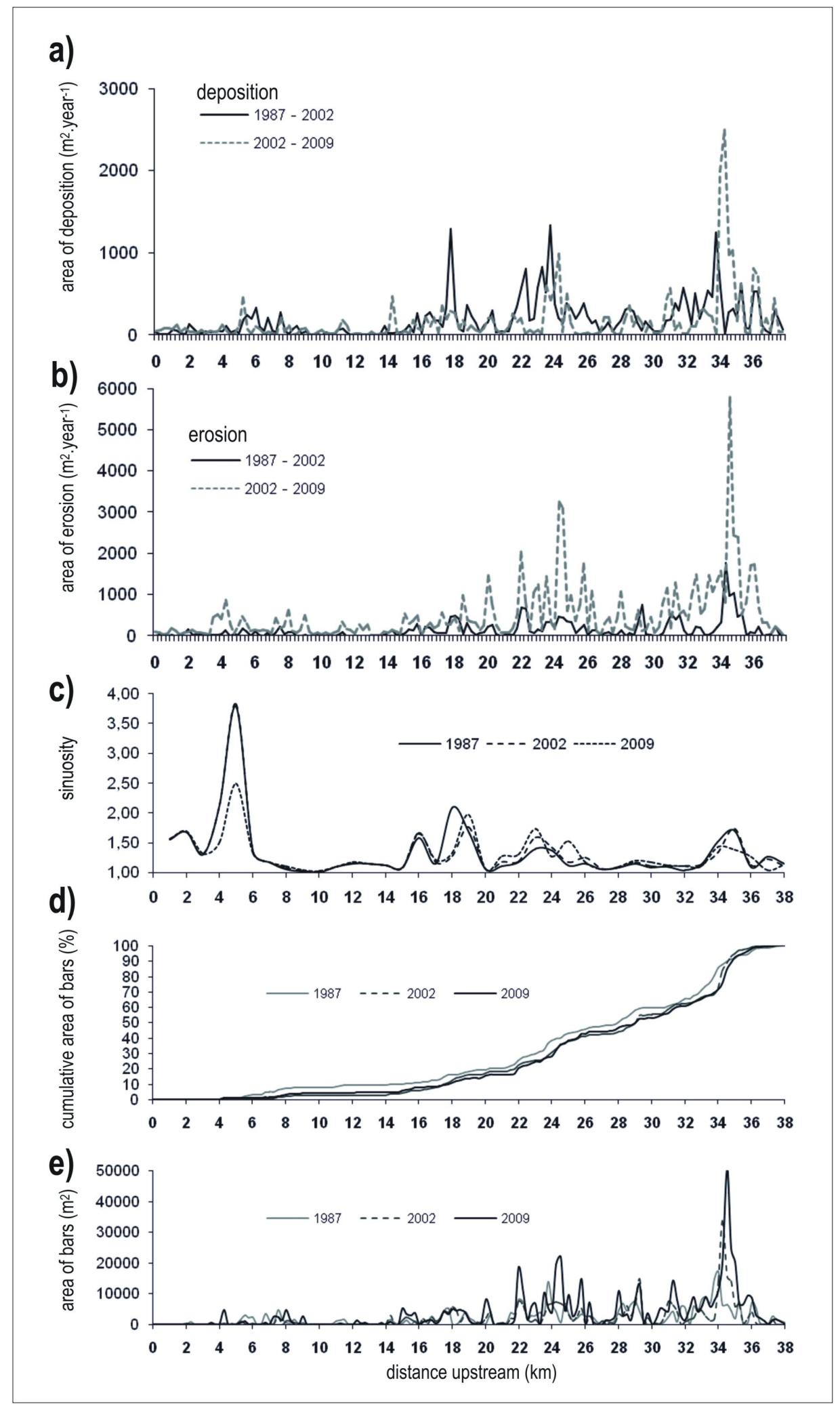

Fig. 3: Longitudinal evolution of (a) deposition, (b) erosion, (c) sinuosity, (d) cumulative area of bars, and (d) area of bars in the study reach of the Topl'a River. Source: authors' calculations 
The increase of erosion was particularly visible between 2002 and 2009. It increased up to 7.6 ha per year which is almost 3.6 times more than in the previous period (1987-2002). Reaches manifesting distinct instability of the channel were identified in the longitudinal direction (Fig. 3). The first and the smaller one ( $\mathrm{km} \mathrm{4-8)} \mathrm{is} \mathrm{linked}$ with the system of meanders north of the town of Giraltovce (Fig. 4). Other similar locations are identifiable between the villages of Harhaj and Kučín (km 15-20), between kilometres 21-26 (in the cadastral territory of the villages Kurima and Dubinné) and north of the village of Hrabovec (km 30-36). They are linked to the reaches with a higher degree of sinuosity (Fig. 3c), where the planform pattern changed in the period 2002-2009.
The average channel shift in the study reach is $12.4 \mathrm{~m}$ (flood period 1987-2002) and $11.3 \mathrm{~m}$ (flood period 20022009) (Tab. 3). The average channel shift per year doubled from $0.8 \mathrm{~m} /$ year (1987-2002) to $1.6 \mathrm{~m} /$ year (2002-2009). A similar development is observable in bedforms where the area of gravel bars almost doubled in 2009. In 1987, they covered an area of 32.7 ha, which represented $26.9 \%$ of the overall channel area, and in 2002 they occupied a comparable area of 31.4 ha ( $28.2 \%$ of the channel area). Their representation increased in 2009 to $37.3 \%$ corresponding to an area of 54.8 ha. This phenomenon is most conspicuous north of Hrabovec (between kilometres 34 and 36), where the area of gravel bars increased from 5.7 ha in 1987 to 16.2 ha in 2009 (in 2002 the area was $9.7 \mathrm{ha}$ ) along the $2 \mathrm{~km}$ reach.

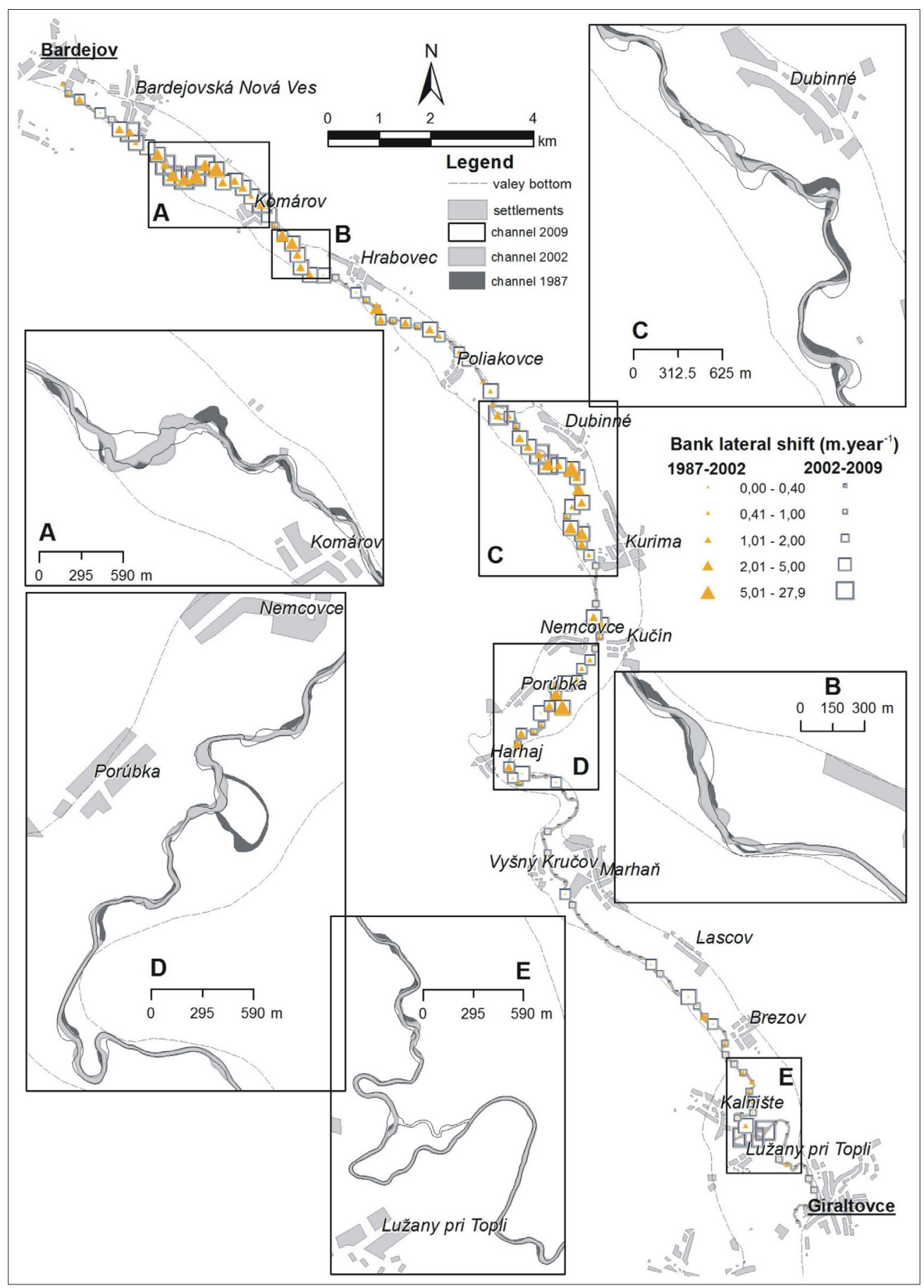

Fig. 4: The spatial distribution of lateral movements of bank line in the two study periods, and locations (A-E) with high lateral instability. Source: authors' calculations; Settlements layer (Geodesy, Cartography and Cadastre Authority of Slovak Republic (122-24-99-2012)) 


\begin{tabular}{|c|c|c|c|c|c|c|c|}
\hline \multirow{2}{*}{ Flood period } & \multicolumn{4}{|c|}{ Lateral shift $[\mathrm{m}]$} & \multicolumn{3}{|c|}{ Rate of shift $\left[\mathrm{m}\right.$. year $\left.^{-1}\right]$} \\
\hline & total & left bank & right bank & max. shift & total & left bank & right bank \\
\hline $1987-2002$ & 12.4 & 11.4 & 13.5 & 260 & 0.8 & 0.8 & 0.9 \\
\hline 2002-2009 & 11.3 & 10.7 & 12.0 & 445 & 1.6 & 1.5 & 1.7 \\
\hline
\end{tabular}

Tab. 3: Lateral shift of banks and rate of shift per year in the periods 1987-2002 and 2002-2009 Source: authors' calculations

\begin{tabular}{llllccccccc}
\hline & \multicolumn{2}{c}{ Lateral bars } & \multicolumn{2}{c}{ Point bars } & \multicolumn{2}{c}{ Mid-channel bars } & \multicolumn{2}{c}{ Islands } & $\Sigma$ \\
\cline { 2 - 10 } & {$[\mathrm{ha}]$} & {$[\%]$} & {$[\mathrm{ha}]$} & {$[\%]$} & {$[\mathrm{ha}]$} & {$[\%]$} & {$[\mathrm{ha}]$} & {$[\%]$} & {$[\mathrm{ha}]$} \\
\hline 1987 & 22.8 & 69.8 & 6.7 & 20.5 & 3.2 & 9.7 & 0.0 & 0.0 & 32.7 \\
2002 & 24.6 & 78.4 & 3.1 & 9.8 & 3.5 & 11.3 & 0.2 & 0.5 & 31.4 \\
2009 & 39.7 & 72.5 & 9.0 & 16.4 & 4.0 & 7.3 & 2.1 & 3.9 & 54.8 \\
\hline
\end{tabular}

Tab. 4: Changes in in-channel landforms of the Topl'a River expressed by areas and percentage. The greatest intensity in bars changes and islands development was registered in 2009. Source: authors' calculations

The change of structure of individual gravel bars is negligible and is local (Tab. 4).

The most threatened reaches of the Topla River are identifiable based on the average lateral bank shift in individual $250 \mathrm{~m}$ long segments (Fig. 4). The most dynamic reach is located south of the town of Bardejov, where the lateral shift reaches several hundreds of metres and threatens the wastewater treatment plant. The lateral shift also forms extensive gravel bars with the transition of the channel to a wandering river. Several dynamic reaches (located between Bardejov and Dubinné) are bound to points where water course transformation occurs from the abutted to the transversal (free) reaches. Three other very unstable reaches (Fig. 4: detail in C, D and E) are linked to the sinuous channel located in the centre of the valley characterised by typical chute offs and the formation of avulsive channels during floods.

\subsection{Land cover changes in the riparian zone and bank erosion risk}

Between 1987 and 2009, a total of 58.2 ha of riparian forest was eroded in the study reach (Tab. 5). The second mosteroded types of riparian landscape were arable land (19.4 ha) and grasslands and pastures ( $6.8 \mathrm{ha}$ ). The remaining two land cover types (shrubs and urbanised area) were only slightly affected by erosion. The erosion of forest, a result of their dominating representation in the delimited riparian zone, prevails in the reach. From an economic point of view, large destroyed farmland areas are a negative phenomenon (Fig. 5). The resulting damage in the area calculated according to
Decree No. 38/2005 was $€ 29,924.02$ in total; for the period $1987-2002$ it was $€ 13,619$, and in the period 2002-2009 it was $€ 16,304.33$ This calculated value of destroyed areas does not reflect the real market prices of the land.

Erosion of built-up surfaces occurred in two places in the study reach of the Topla. The first is erosion of part of a garden adjacent to an old homestead south of Hrabovec. The second is the destruction of a part of the wastewater treatment plant protective dike, located beyond the city of Bardejov, and disablement of the small hydropower station built in the meander bend (Fig. 6) due to its improper siting. The wastewater treatment plant was again threatened and the bank further eroded during the extreme flood of 2010 .

Newly-formed deposition areas, which are created in the space of the old channel after its shifting by erosion, are progressively covered by natural succession. The result is a visible increase of the proportion of the riparian forest, which gradually replaces other eroded landscape structure types in the riparian zone (such as arable land or grassland): see Table 5.

\section{Discussion}

The channel's lateral shift, its width and the bedforms area of the reach studied, are affected by discharge in the short term, as they are controlled by the magnitude and frequency of floods and by the duration of low-stage periods. The increase of bank erosion after 2002 in the reach studied is obvious. In the first period, the rate of erosion and deposition were in approximate balance with

\begin{tabular}{llccccc}
\hline \multirow{2}{*}{ Flood period } & \multirow{2}{*}{ Process } & \multicolumn{5}{c}{ Land cover category [ha] } \\
\cline { 3 - 7 } & & 1 & 2 & 3 & 4 & 5 \\
\hline \multirow{2}{*}{$1987-2002$} & erosion & 20.1 & 0.3 & 3.9 & 7.5 & 0.1 \\
& deposition & 40.9 & 0.3 & 1.2 & 0.0 & 0.0 \\
\multirow{2}{*}{$2002-2009$} & erosion & 38.1 & 0.5 & 2.9 & 11.9 & 0.1 \\
& deposition & 16.8 & 0.0 & 0.7 & 0.1 & 0.0 \\
\hline
\end{tabular}

Tab. 5: Erosion of land cover categories in the riparian zone (ha) and the area of new land cover categories formed on the deposition areas after the lateral movement of the channel in the two study periods. Land cover categories: 1) riparian forest, 2) shrubs, 3) grassland and pastures, 4) arable land, 5) urbanised area.

Source: authors' calculations 


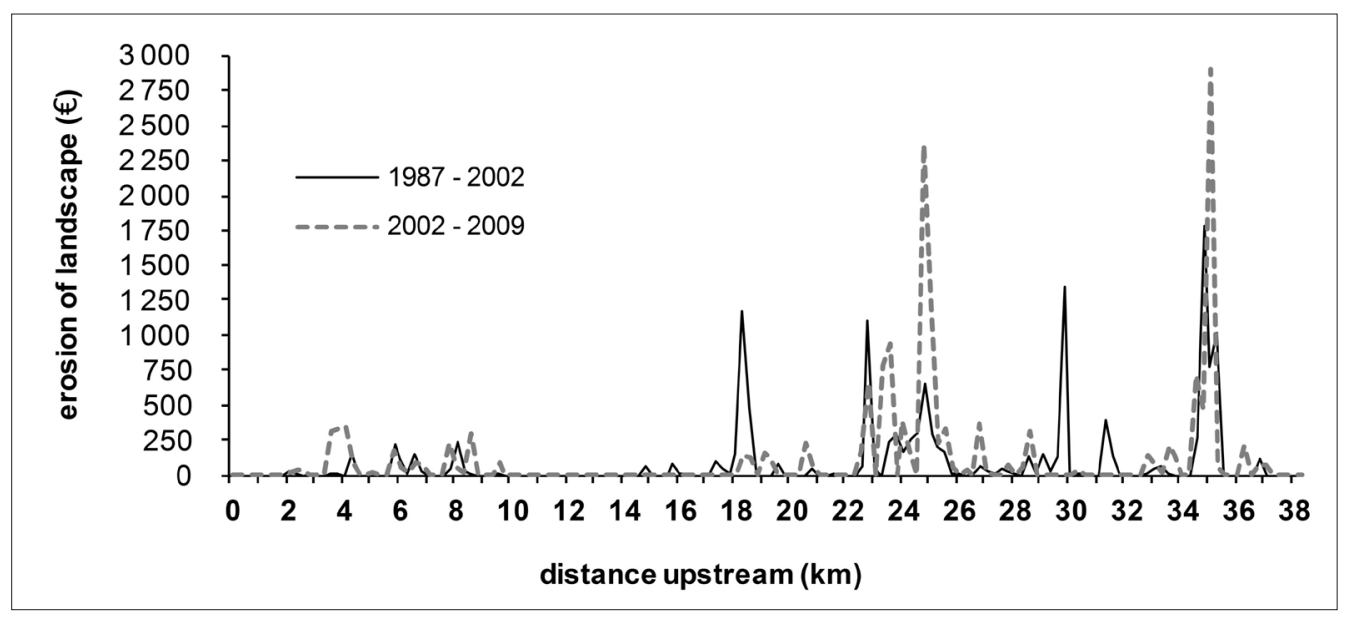

Fig. 5: Longitudinal evolution of the erosion of grassland, pastures and arable land in monetary terms (€) Source: Authors' calculations

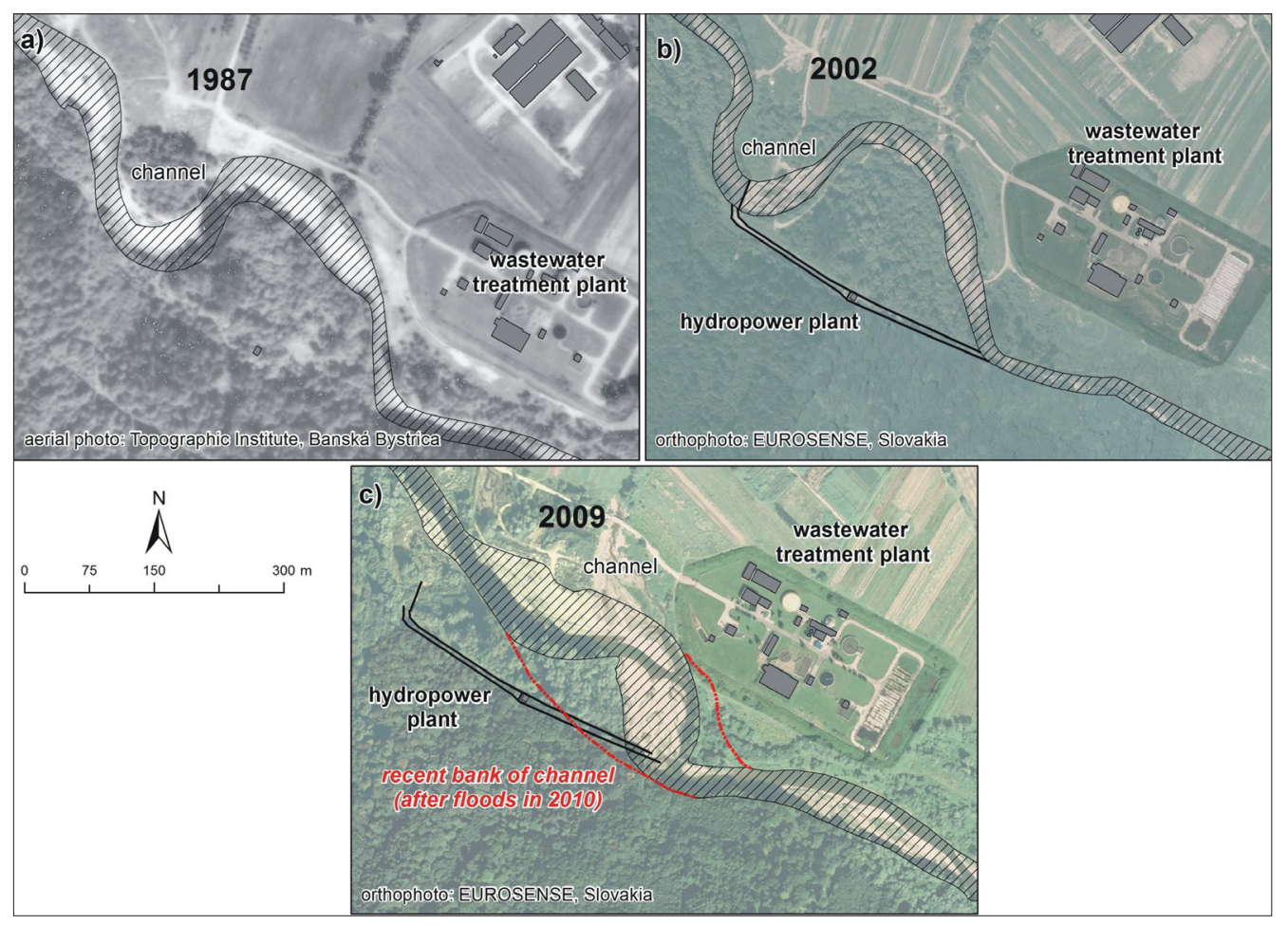

Fig. 6: a) Channel position in 1987; b) The channel position in 2002 with the small hydropower plant constructed in the meander loop in 2000; c) The changed channel planform in 2009 due to flood events in the second flood period leading to the dike's destruction close to the wastewater treatment plant, and the disablement of the hydropower plant as the consequence of its improper siting at the laterally active meander loop

Source: authors' elaboration; aerial photo (Topographic Institute, Banská Bystrica and EUROSENSE, Slovakia)

a slight prevalence of deposition. Due to the response of the river to the phase of low magnitude floods after events in 1987 and 1989, the channel narrowed from the average width of $31.4 \mathrm{~m}$ to $28.7 \mathrm{~m}$ and stabilised. Small discharges with a recurrence interval 1 or 2 years, which occurred in the reach between 1989 and 2000, did not exert larger destructive effects. On the contrary, in accord with Corenblit et al. (2007) and Phillips (2002), their effect was constructive and contributed to the stabilisation of the system. On the other hand, high magnitude and frequent floods after 2002 (and especially in 2004, 2006 and 2008) intensified erosion processes - the area of erosion compared to the area of deposition increased 3.6-fold and the average shift of the bank doubled. The result was widening of the channel to an average width of about $38 \mathrm{~m}$.
Some authors (Bertoldi et al., 2009, or Hickin and Sichingabula, 1988) emphasise the predominant role of the channel-forming discharge or relatively smaller but longduration floods in bank or floodplain erosion. As Lehotský et al. (2013) or Phillips (2002) point out, it is precisely the smaller discharge that leads to channel and planform formation and relatively slower bank erosion, which is connected with the overall behaviour of the river in the stage of dynamic equilibrium and hydraulic flow in the river bend (Hickin and Nanson, 1984). High magnitude floods lead to sudden and significant bank erosion, destruction of the planform and to partial or total rejuvenation of the stream, accompanied by channel and gravel bars expansion, and the destruction of old and formation of new stands for vegetation. 
While bank erosion in bends is more or less continuous, its rate depends on the discharge régime. Therefore, channel shifting changes rhythmically; because of the lateral erosion, the channel widens and creates favourable conditions for the formation of large bar surfaces. This process is more pronounced if floods return frequently, enhancing bank erosion, and the stabilisation of the vegetation is limited. If years characterised by low discharges occur, however, the arboreous vegetation can stabilise the bar surfaces, leading to channel narrowing (Kiss and Blanka, 2012). Consequently, the changes in the characteristic stages and frequency of floods since 1987 can highly influence the long-term tendencies of channel migration and bedforms evolution. Individual landforms are formed and reformed in new locations, but they retain their generic identity as part of a landform assemblage. Thus, the Topla as a meandering river is deemed to be "robust" if, over decades, it steadily migrates creating bars/point bars, which, in turn, are incorporated into a new floodplain, but yet retains its characteristic morphology of pools, riffles, undercut banks and bars/point bars. This can be described as "robust" behaviour within existing intrinsic thresholds, rather than "responsive" behaviour crossing extrinsic thresholds (Werritty and Leys, 2001). Not only does bank erosion lead to the development of new geomorphic diversity of a river, but it also provides several ecosystem services (Cebecauerová and Lehotský, 2012). Bank erosion may also have a psychological effect (Piégay et al., 1997).

The majority of eroded banks are located in less valuable places than settlements or arable land. The monetary expression of the damage caused by the bank erosion of arable land and pastures normally concern the unstable stretches (Fig. 7). The attention of water authorities or managers should focus precisely on these dynamic reaches, along with those where the stream directly threatens human activities.
The calculated prices of eroded agricultural land reflect the prices set by Slovak law, which differ from those of the market. The actual market price of a plot of arable land in this area is two to three times higher. Ignorance of stream dynamics and behaviours often leads to the application of expensive and inappropriate interventions, which do not respect the natural development of the channel (Langhammer, 2010) (Fig. 8). An example of such inappropriate intervention is the location of the above-mentioned small hydropower plant. For a natural and healthy river state, the self-regulatory mechanism which leads to spontaneous self-organisation into a quasi-new balanced status is important.

Extreme discharges cause considerable bank erosion and the formation of new bar areas, which lead to a loss of arable land and the destruction of buildings. Bank failure occurrence indicates potential erosion in future years because they are not fixed by vegetation (Grešková and Lehotský, 2007), indeed even minor bank erosion related to the growth of channel loops leads to bank migration, but over a longer time frame.

\section{Conclusions}

Understanding the dynamics and behaviour of rivers in their natural environment and in the context of other components of landscape, makes it possible to predict the future development of the stream and its environs. It may simplify the co-existence of humans and the river and limit negative man-made interference with streams.

The Topla River reach, as an unconfined gravel-bed river system, is typical for its migratory behaviour and obvious bank erosion. It is still one of the few minimally trained river reaches in the Slovak Republic and, therefore, ideal for contemporary monitoring of the dynamics of a river system. Gradual loss and bank destruction along the concave banks and deposition of material on the opposite

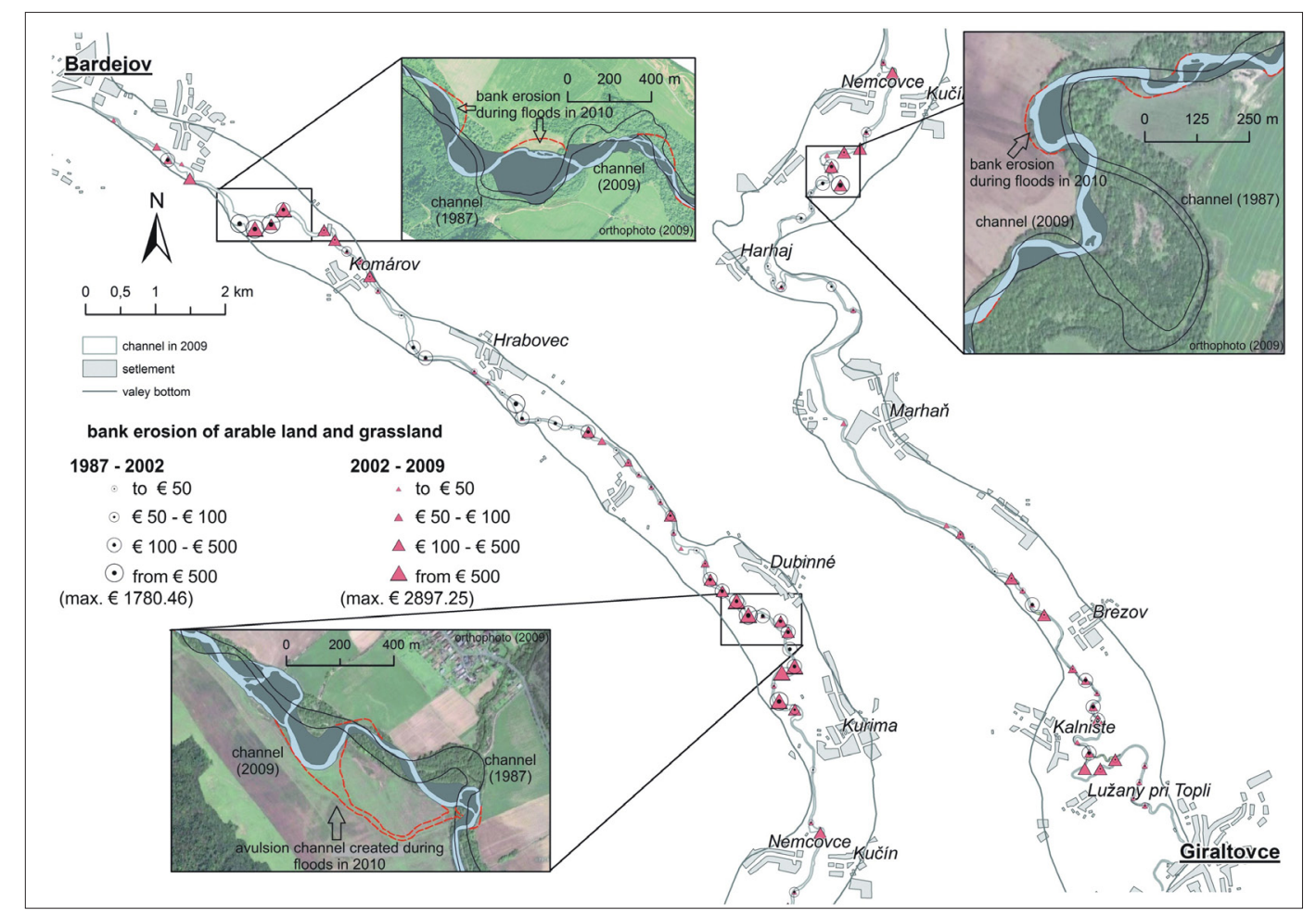

Fig. 7: Localities of grassland, pasture and arable land plots destroyed by bank erosion, and expressed by value (€) according to state-determined prices

Source: authors' elaboration; Settlements layer (Geodesy, Cartography and Cadastre Authority of Slovak Republic (122-24-99-2012)); aerial photo (EUROSENSE, Slovakia) 


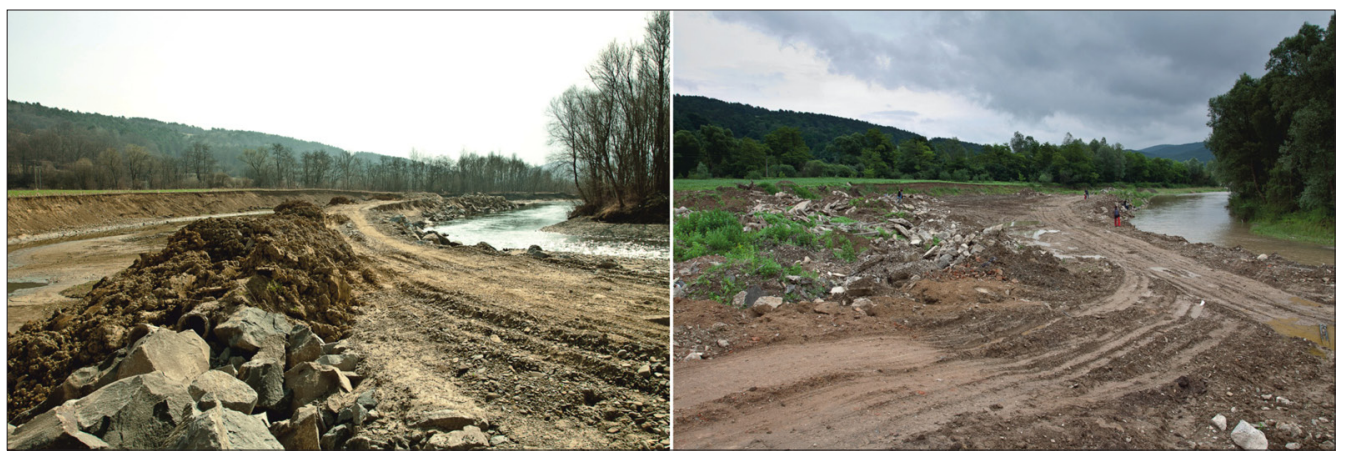

Fig. 8: An example of non-environmentally friendly river management. Channel lateral movement and bank erosion in the meander loop was stopped by the dike and the channel was shifted to the position before the flood event (left image). The inter-dike area close to the eroded bank was filled downstream by construction waste (right image). Despite these measures, channel migration continues. Photo: M. Rusnák

banks, are the processes that take place along the stream. The size of the shift itself is considerable - it moves about one metre per year and more than $10 \mathrm{~m}$ per year in the most dynamic reaches. The shift of the channel manifests itself by the formation of cutting banks and undercutting former floodplain and slope terraces. The channel shift is responsible for the change and destruction of the existing landforms and the deposition of new ones, followed by succession of vegetation and overall land cover changes in the riparian zone. Two different flood periods (1987-2002 and 2002-2009) with two different channel behaviours have been identified. The average channel shift per year doubled from $0.8 \mathrm{~m} /$ year (1987-2002) to $1.6 \mathrm{~m} /$ year (20022009). In total, an area of 85.2 ha was eroded and 60.1 ha was deposited. The most eroded land cover category in the riparian zone is floodplain forest, followed by arable land, grasslands and pastures and shrubs. From an economic point of view, the eroded floodplain with arable land and grassland ( $€ 29,924.02$ in total) are negative consequences of channel migration. It is also necessary to bear in mind that channel migration and bank erosion are natural processes. A "green" approach is now preferred worldwide, one which avoids technical interventions into the channels and rivers are left to meander freely in certain areas (Piégay et al., 2005) or in certain reaches (Piégay et al., 1997). Piegay et al. (1997) also point out that active restrictive interventions in channels are expensive and result in a spiral effect leading to the degradation of streams and increased flood risk. Fortunately, the study river reach is a good example of a situation where the channel migration, bank erosion and bank destruction processes are not given much attention by local authorities.

\section{Acknowledgments}

The research was supported by the Science Grant Agency (VEGA) of the Ministry of Education of the Slovak Republic and the Slovak Academy of Sciences: 02/0020/15. The hydrological data were provided by the Slovak Hydrometeorological Institute.

\section{References:}

BERTOLDI, W., GURNELL, A. M., SURIAN, N., TOCKNER, K., ZANONI, L., ZILIANI, L., ZOLEZZI, G. (2009): Understanding reference processes: linkages between river flows, sediment dynamics and vegetated landforms along the Tagliamento River, Italy. River Research and Applications, 25: 501-516.
BRÁZDIL, R., KUNDZEWICZ, Z. W., BENITO, G. (2006): Historical hydrology for studying flood risk in Europe. Hydrological Sciences Journal, 51(5): 739-764.

BRÁZDIL, R., MÁČKA, Z., ŘEZNÍČKOVÁ, L., SOUKALOVÁ, E., DOBROVOLNÝ, P., GRYGAR, T. M. (2011): Floods and floodplain changes of the River Morava, the Strážnické Pomoraví region (Czech Republic) over the past 130 years. Hydrological Sciences Journal, 56(7): 1166-1185.

BRIERLEY, G. J., FRYIRS, K. A. (2005): Geomorphology and river management: Application of the River Styles Framework. Oxford, Blackwell Publications.

BRONSTERT, A. (2003): Floods and climate change: interactions and impacts. Risk Analysis, 23(3): 545-567.

BRYANT, R. G., GILVEAR， D. J. (1999): Quantifying geomorphic and riparian land cover changes either side of a large flood event using airborne remote sensing: River Tay, Scotland. Geomorphology, 29: 307-321.

CEBECAUEROVÁ, M., LEHOTSKÝ, M. (2012): Komplexita ripariálnej zóny - príklad rurálneho segment vodného toku Torysa. Geografický časopis, 64(2): 133-154.

CORENBLIT, D., STEIGER, J., GURNELL, A. M., TABACCHI, E., ROQUES, L. (2007): Control of sediment Dynamics by vegetation as a key function driving biogeomorphic succession within fluvial corridors. Earth Surface Processes and Landforms, 34: 1790-1810.

CORENBLIT, D., STEIGER, J., TABACCHI, E. (2010): Biogeomorphologic succession dynamics in a Mediterranean river system. Ecography, 33: 1136-1148.

DECREE No. 38/2005 of the Ministry of Agriculture and Rural Development of the Slovak Republic on prices of plots and growths for the purpose of land arrangements.

DRAUT, A. E., LOGAN, J. B., MASTIN, M. C. (2011): Channel evolution on the dammed Elwha River, Washington, USA. Geomorphology, 127 71-87.

ERSKINE, W., KEENE, A., BUSH, R., CHEETHAM, M., CHALMERS, A. (2012): Influence of riparian vegetation on channel widening and subsequent concentration on sand-bed stream since European settlement: Widden Brook, Australia. Geomorphology, 147-148: 102-114.

FRYIRS, K. A., BRIERLEY, G. J. (2013): Geomorphic Analysis of River Systems: An Approach to Reading the Landscape. Oxford, Wiley-Blackwell. 
FULLER, I. C. (2008): Geomorphic impacts of a 100-year flood: Kiwitea Stream, Manawatu catchment, New Zealand. Geomorphology, 98: 84-95.

GILVEAR, D., BRYANT, R. (2003): Analysis of aerial photography and other remotely sensed data. In: Kondolf, M., Piégay, H. [eds.]: Tools in geomorphology (pp. 135-170). Chichester, Wiley.

GILVEAR, D., WILLBY, N. (2006): Channel dynamics and geomorphic variability as controls on gravel bar vegetation, River Tummel, Scotland. River Research and Applications, 22: 457-474.

GURNELL, A. M., PETTS, G. E. (2002): Island-dominated landscapes of large floodplain rivers, a European perspective. Freshwater Biology, 47: 581-600.

GURNELL, A. M., PETTS, G. E. (2006): Trees as riparian engineers: The Tagliamento River, Italy. Earth Surface Processes and Landforms, 31: 1558-1574.

GREŠKOVÁ, A., LEHOTSKÝ, M. (2007): Vplyv lesných brehových porastov na správanie a morfológiu riečneho koryta. Geomorphologia Slovaca et Bohemica, 7(1): 36-42.

HICKIN, E. J., NANSON, G. C. (1984): Lateral migration rates of river bends. Journal of Hydraulic Engineering, 110: 1557-1567.

HICKIN, E. J., SICHINGABULA, H. M. (1988): The geomorphic impact of the catastrophic October 1984 flood on the planform of Squamish River, southwestern British Columbia. Canadian Journal of Earth Sciences, 25: 1078-1087.

HOOKE, J. M. (1979): An analysis of the processes of river bank erosion. Journal of Hydrology, 42: 39-62.

HOOKE, J. M. (2015): Variations in flood magnitude-effect relations and the implications for flood risk assessment and river management. Geomorphology, 251: 91-107.

HOOKE, J. M., REDMOND, C. E. (1989): Use of Cartographic Sources for Analyzing River Channel Change with Examples from Britain. In: Petts, G. E. [ed.]: Historical Change of Large Alluvial Rivers: Western Europe (pp. 79-93). Chichester, John Wiley and Sons.

HRÁDEK, M. (2000): Geomorfologické účinky povodně v červenci 1997 na území severní Moravy a Slezska. Geografický časopis, 52(4): 303-321.

KIDOVÁ, A., LEHOTSKÝ, M., RUSNÁK, M. (2016): Geomorphic diversity in the braided-wandering Belá River, Slovak Carpathians, as a response to flood variability and environmental changes. Geomorphology, in press. http://dx.doi.org/10.1016/j. geomorph.2016.01.002

KISS, T., BLANKA, V. (2012): River channel response to climate- and human-induced hydrological changes: Case study on the meandering Hernád River, Hungary. Geomorphology, 175-176: 115-125.

KISS, T., FIALA, K., SIPOS, G. (2008): Alterations of channel parameters in response to river regulation works since 1840 on the Lower Tisza River (Hungary). Geomorphology, 98(1-2): 96-110.

KNIGHTON, D. (1998): Fluvial forms and processes. A new perspective. London, Hodder Arnold.

KOVÁČIK, M. [ed.], BÓNA, J., GAZDAČKO, L., KOBULSKÝ, J., MAGLAY, J., ŽECOVÁ, K., DERCO, J.,
ZLINSKÁ, A., SIRÁŇOVÁ, Z., BOOROVÁ, D., BÓNOVÁ, K., BUČEK, S., KUCHARIČ, L., KUBEŠ, P., BAČOVÁ, N., PETRO, L., VANĚKOVÁ, H. (2011): Geologická mapa Nízkych Beskýd - v. časte. 1: 50000. MŽP SR-ŠGÚDŠ, Bratislava.

LANGHAMMER, J. (2010): Analysis of the relationship between the stream regulations and the geomorphologic effects of floods. Natural Hazards, 54: 121-139.

LANGHAMMER, J., VILÍMEK, V. (2008): Landscape changes as a factor affecting the course and consequences of extreme floods in the Otava river basin, Czech Republic. Environmental Monitoring and Assessment, 144(1-3): 53-66.

LARSEN, E. W., FREMIER, A. K., GRECO, S. E. (2006): Cumulative effective stream power and bank erosion on the Sacramento River, California, USA. Journal of the American Water Resources Association, 42(4): 1077-1097.

LAWLER, D. M., THORNE, C. R., HOOKE, J. M. (1997): Bank erosion and instability. In: Thorne, C. R., Hey, R. D., Newson, M. D. [eds.]: Applied Fluvial Geomorphology for River Engineering and Management (pp. 138-172). Chichester, Wiley.

LEHOTSKÝ, M., FRANDOFER, M., NOVOTNÝ, J., RUSNÁK, M., SZMAŃDA, J. B. (2013): Geomorphic/ Sedimentary responses of rivers to floods: Case studies from Slovakia. In: Lóczy, D. [ed.]: Geomorphological impacts of extreme weather: Case studies from central and eastern Europe (pp. 37-52), Dordrecht, Springer.

LUPPI, L., RINALDI, M., TERUGGI, L., DARBY, S., NARDI, L. (2009): Monitoring and numerical modelling of riverbank erosion processes: a case study along the Cecina River (central Italy). Earth Surface Processes and Landforms, 34: 530-546.

MICHALKOVÁ, M., PIÉGAY, H., KONDOLF, G. M., GRECO, S. E. (2011): Lateral Erosion of the Sacramento River, California (1942-1999), and responses of channel and floodplain lake to human influences. Earth Surface Processes and Landforms, 36: 257-272.

MILLER, A. J. (1990): Flood hydrology and geomorphic effectiveness in the Central Appalachians. Earth Surface Processes and Landforms, 15: 119-134.

OPPERMAN, J. J., LUSTER, R., MCKENNEY, B. A., ROBERTS, M., MEADOWS, A. W. (2010): Ecologically functional floodplains: connectivity, flow regime, and scale. Journal of the American Water Resources Association, 46(2): 211-226.

PEKÁROVÁ, P., MIKLÁNEK, P., PEKÁR, J. (2003): Spatial and temporal runoff oscillation analysis of the main rivers of the world during the $19^{\text {th }}-20^{\text {th }}$ centuries. Journal of Hydrology, 274: 62-79.

PEKÁROVÁ, P., MIKLÁNEK, P., PEKÁR, J. (2010): Možnosti dlhodobej predikcie prietokov slovenských tokov na základe indexu Severoatlantickej oscilácie. Acta Hydrologia Slovaca, 11(2): 282-290.

PIÉGAY, H., CUAZ, M., JAVELLE, E., MANDIER, P. (1997): Bank erosion management based on geomorphological, ecological and economic criteria on the Galaure River, France. Regulated Rivers-research \& Management, 13: $433-448$. 
PIÉGAY, H., DARBY, S. E., MOSSELMAN, E., SURIAN, N. (2005): A Review of Techniques Available for Delimiting the Erodible River Corridor: A Sustainable Approach to Managing Bank Erosion. River Research and Applications, 21: 773-789.

PIŠÚT, P. (2002): Channel evolution of the pre-channelized Danube River in Bratislava, Slovakia (1712-1886). Earth Surface Processes and Landforms, 27: 369-390.

PIŠÚT, P. (2008): Endangerment of the village Čunovo (Slovakia) by lateral erosion of the Danube River in the $18^{\text {th }}$ Century. Moravian Geographical Reports, 16: 33-44.

PHILLIPS, J.D. (2002): Geomorphic impacts of flash flooding in a forested headwater basin. Journal of Hydrology, 269: 236-250.

RICHARD, G. A., JULIEN, P.Y., BAIRD, D. C. (2005): Statistical analysis of lateral migration of the Rio Grande, New Mexico. Geomorphology, 71: 139-155.

RUSNÁK, M., LEHOTSKÝ, M. (2014): Time-focused investigation of river channel morphological changes due to extreme floods. Zeitschrift für Geomorphologie, 58(2): 251-266.
RUSSELL, J. A., BLEDSOE, B. P., HESSION, W. C. (2004): Width of streams and rivers in response to vegetation, bank material, and other factors. Journal of the American Water Resources Association, 40: 1159-1172.

SIMON, A., CURINI, A., DARBY, S. E., LANGENDOEN, E. J. (2000): Bank and near-bank processes in an incised channel. Geomorphology, 35: 193-217.

WARD, J. V., TOCKNER, K., ARSCOTT, D. B., CLARET, C. (2002): Riverine landscape diversity. Freshwater Biology, 47: 517-539.

WERRITTY, A., LEYS, K. F. (2001): The sensitivity of Scottish rivers and upland valley floors to recent environmental change, Catena, 42: 251-273.

ZANONI, L., GURNELL, A., DRAKE, N., SURIAN, N. (2008): Island dynamics in a braided river from analysis of historical maps and air photographs. River Research and Applications, 24: 1141-1159.

\section{Please cite this article as:}

RUSNÁK, M., LEHOTSKÝ, M., KIDOVÁ, A. (2016): Channel migration inferred from aerial photographs, its timing and environmental consequences as responses to floods: A case study of the meandering Topla River, Slovak Carpathians. Moravian Geographical Reports, 24(3): 32-43. Doi: 10.1515/mgr-2016-0015. 